\title{
上気道炎分離株に対するセフェム系抗生剤の 抗菌力ならびに組織内濃度の検討
}

\author{
藤巻 豊 - 河村 正三・杉田 麟也* $*$ 大沢 博之** \\ 出口 浩一*** - 小島 敏昌・市川 正人****
}

\section{A Study on Antimicrobial Activity and Tissue Levels of a Cephem Antibiotic in Upper Respiratory Tract Infection}

\author{
Yutaka Fujimaki, Shozo Kawamura and Rinya Sugita \\ (Juntendo University) \\ Hiroyuki Osawa \\ (Koshigaya Municipal Hospital) \\ Koichi Deguchi \\ (Tokyo Clinical Research Center) \\ Toshimasa Kojima and Masato Ichikawa \\ (Products Development Laboratories Sankyo Co., Ltd)
}

The usefulness of cefmetazole (CMZ), a cephem antibiotic, in the treatment of upper respiratory tract infections was assessed in respect to antibacterial activity and antibiotic concentrations in tissues.

The in vitro antibacterial activity was determined by the re-revised minimum inhibitory concentration (MIC) assay procedure of the Japanese Society of Chemotherapy. For estimation of tissue antibiotic concentrations, specimens of the palatine tonsilla and maxillary sinus mucosa obtained at operation from patients given an intravenous dose of 1-2 $\mathrm{g}$ of CMZ or cefazolin (CEZ) were assayed by the thin agar layer-cup method and sensitivity disc method, using Micrococcus luteus ATCG 9341 or Bacillus subtilis ATCG 6633 as the test organism, respectively.

Results:

1) The antimicrobial susceptibility tests revealed an increased activity against Haemophilus influenzae and indole-positive Proteus isolates.

2) There was a remarkable proximity of the MIC and minimum bactericidal concentration $(\mathrm{MBC})$ of $\mathrm{CMZ}$ against the various clinical isolates in vitro.

*順天堂大学医学部耳鼻咽唉科学教室

$* *$ 越谷市立病院耳鼻咽喉科

***東京総合臨床検査センター研究部

****三共侏生产技術研究所 
3) Ten to $40 \%$ of the serum level of CMZ were demonstrated in the maxillary sinus mucosa and palatine tonsils. These tissue levels sufficiently surpassed the MICs of frequent isolates from upper respiratory tract infections.

4) The tonsil level of CEZ, another cephem antibiotic, was about the same as that of CMZ, but the rate of transfer from the serum to tonsils was less variable in the case of CEZ.

The results indicate considerable usefulness of $\mathrm{CMZ}$ in the treatment of upper respiratory tract infections.

\section{緒言}

感染症に対する治療目的に抗生物質を投与するときには。病巣における分離頻度の高い菌に対し て抗菌力を有する薬剂を投与することが大切である，また，投与された楽剂は病巣において有効な 組織内濃度に達し，しかも，その濃度を一定時間持続することが必要である。

耳鼻咽喉科領域での抗生物質の組織移行に関しては, 高須 ${ }^{1)}$, 三好 ${ }^{21}$, 岩沢 ${ }^{3) 4)}$, 三吉 ${ }^{5)}$, 守安 ${ }^{6)}$ の報告がある.

今回, 著者らはセファマイシン系抗生物質, Cefmetazole（以下 CMZ 上畍す）の上気道炎に対 する有用性を基礎的に検讨した。

$\mathrm{CMZ}$ はセファロスポリン骨格の $7 \alpha$ 位にメトキシ基の人ったセファマイシン系構造を有する楽 剂である(図 1 ).

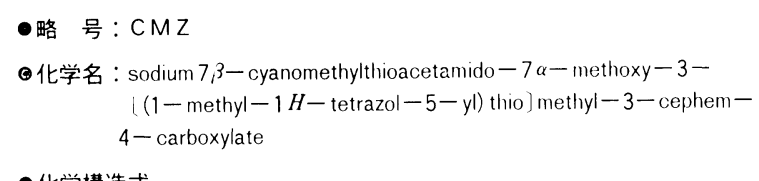

-化学構造式

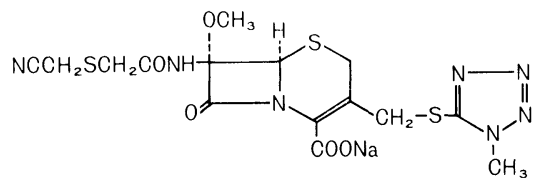

図। セフメタゾールの䟵造式

いままでに，本剤は $\beta$-lactamase を産生するセファロスポリン耐性菌，ペニシリン耐性菌に もすぐれた抗菌力を示すとと, 扰よび, 強い抗菌力を有し, 殺菌的に作用することが報告されてい る.

今回, 著者らは日常䛦療にてえられた細菌学的検案の絬果をまじえ, CMZの上気道炎に刘する 有用性を基礎的に検討し，興味ある知見がえられたので文献的考祭を加えて報告する。

\section{対象および方法}

1) 対象

対象症例は1980年 2 月より1981年 9 月までに 順大堂大学耳鼻咽喉科, 江東病院耳鼻咽喉科沶 よび越谷市立病院耳鼻咽喉科佂院し府桃摘出 術を受けた15才以下の小坚23例および慢性副鼻
腔炎根治術を受けた 15 才以上の成人 30 例であ る. 扁桃摘出術は全身林酔 (GOF) 飞て, 慢 性副鼻腔炎根治術は局所林酔 (0.5\% キシロカ イン +20 万倍アドレナリン) にて行なった。

2 ) 細菌学的検就 
i ) 薬剂の M I C (Minimum inhibitory concentration) 測定

以下の細菌学的検查は東京総合陵床検查セン ター研究部で行なった，M I C 測定は，日本化 学療法学会MI C 測定法 (再改訂) $)^{8}$ 亿従った。 接種菌量は $10^{6} \mathrm{CFU} / \mathrm{ml}, 10^{8} \mathrm{CFU} / \mathrm{ml}$ の両方 である。

平板培地はM I C 測定用培地（日水）および TCS-Agar（栄研）を基礎培地とした $7 \%$ \%ウサ ギ血液寒天培地, GAM 寒天培地 (日水), 于 ョコレート寒天培地を使用した。

増菌用および菌液調製用培地には trypticase soy broth (B B L ) および G AMブィヨン培 地（日水）を用いた。

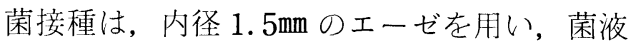
の調製抒よび判定す法は M I C 再改訂法 ${ }^{8}$ 飞従 った。

ii) 薬剂 $\odot \mathrm{MBC}$ (Minimum bactericidal concentration）測定

検定菌は,グラム陽性球菌では Staphylococcus aureus FDA 209P JC-1 をグラム陰 性悍菌では Escherichia coli NIHJ JC-2 を 用いた。下記の種々の濃度の $\mathrm{CMZ}$ 之接触さ 女，経時的に生菌数を測定した。実験開始時に は，菌量をいずれの埸合む $10^{6.7} \mathrm{CFU} / \mathrm{ml}$ に調 製した。 $\mathrm{CMZ}$ 濃度は，0，0.78，1.56，3.13， $6.25 \mu \mathrm{g} / \mathrm{ml}$ と変え, $\mathrm{CMZ}$ 源加後 48 封間まで生 菌数を測定した。な沶 E. coli NIHJ JC-2, S. aureus FDA 209P JC-1 に対する CMZの M I Cはそれぞれ $1.56 ， 0.78 \mu \mathrm{g} / \mathrm{ml}$ であった。

3 ) 組織内濃度测定

$\mathrm{CMZ}$ 0.6，1 あるいは $2 \mathrm{~g}$ を静脈内に one shot 注射後, 一定侍間後に組織を摘出し付着 血液を生理住塩水で十分洗い渚したのち測定時 間まで $-80^{\circ} \mathrm{C}$ に凍結保存した。同時に静脈血む 採取し血清分離後 $-80^{\circ} \mathrm{C}$ に凍結保存した。組織 は $1 \% \mathrm{PBS}$ (phosphate buffer solution) （pH 6.0）を加えてホモジェナイズし抽出液部 分を Micrococcus luteus ATCC 9341 を試駗 菌とする薄層ディスク法で測定した。乙れら試
料の测定には $1 \%$ P B S（pH 6.0）で標準液系 列を作成した。血清の測定は上記試験菌を用い る溥痋カップ法で行ない，標準液系列の作成に は Moni-Trol I を用いた。えられた血清中C $M Z$ 濃度の桨動力学的解析には以下に示す two compartment open model を使用し, (1) 式で 血清中 C M Z 濃度をシミュレートした。

\section{Central \\ Tissue \\ Compartment \\ Compartment}
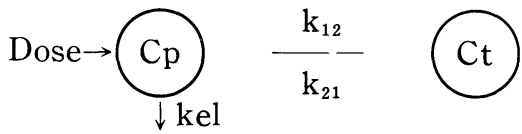

$\mathrm{Cp}=\frac{\operatorname{Dose}\left(\alpha-\mathrm{k}_{21}\right)}{\mathrm{Vc}_{\mathrm{c}}(\alpha-\beta)} \mathrm{e}^{-\alpha \mathrm{t}}+\frac{\operatorname{Dose}\left(\mathrm{k}^{21}-\beta\right)}{\mathrm{V}_{\mathrm{c}}(\alpha-\beta)} \mathrm{e}^{-\beta \mathrm{t}}$

$\alpha$ : 分死速度定数

$\beta:$ 消失速度定数

Vc: Ccntral Compartment $の$ 分布容積

$\mathrm{k}_{12}$ : Central Compartment から Tissue Compartment への移行速度定数

$\mathrm{k}_{21}$ : Tissue Compartment から Central Compartment への移行速度定数

な技，上䛉のパラメーターのうち， $\alpha, \beta$, $\mathrm{k}_{12} ， \mathrm{k}_{21}$ は真下 ${ }^{7)}$ らが報告した健康人に CMZ を $1 \mathrm{~g}$ 静脈内投与後得られた血清中 CMZ濃度 の時間推移のデータを(1)式にフィットさせて繰 り返し，重み付き最小二乘法で計算するという 方法によって求めた。 てのようにして得た $\alpha=$ $9.12\left(\mathrm{~h}^{-1}\right)=0.152\left(\mathrm{~min}^{-1}\right), \quad \beta=0.69\left(\mathrm{~h}^{-1}\right)$ $=0.0115\left(\mathrm{~min}^{-1}\right), \quad \mathrm{k}_{21}=4.55\left(\mathrm{~h}^{-1}\right)=0.0758$ $\left(\mathrm{min}^{-1}\right)$ を(1)式に代入して $(1)^{\prime}$ 式を得た。(1) 式 に得られた各被䥒者の血清中濃度を代入し，各 被験者の $\mathrm{Vc}$ を求め，(2)式により算術平均した $\overline{\mathrm{V}} \mathrm{c}$ を(1)式に代入して, 血清中 $\mathrm{CMZ}$ 濃度をシ ミュレートした。

$$
\begin{aligned}
\mathrm{Vc}= & \frac{1}{\mathrm{Cp}}\left(\frac{\operatorname{Dosc}\left(\alpha-\mathrm{k}_{21}\right)}{(\alpha-\beta)} \cdot \mathrm{e}^{-\alpha t}\right. \\
& \left.+\frac{\operatorname{Dose}\left(\mathrm{k}_{21}-\beta\right)}{(\alpha-\beta)} \mathrm{e}^{-\beta \mathrm{t}}\right) \ldots \ldots \\
\mathrm{Vc}= & \frac{\sum_{\mathrm{t}=1}^{\mathrm{n}} \cdot \mathrm{V}_{\mathrm{cn}}}{\mathrm{n}} \ldots \ldots \ldots \ldots \ldots \ldots \ldots \ldots \ldots \ldots
\end{aligned}
$$


また，乙の時の組織中の $\mathrm{CMZ}$ 濃度は(3)式で 記述されることから同様にして $\mathrm{k}_{12}=3.85\left(\mathrm{~h}^{-1}\right)$ $=0.0642\left(\mathrm{~min}^{-1}\right)$ を使用して Vt を求め, 組織 中の CMZ濃度をシミュレートした。

$$
\mathrm{Ct}=\frac{\mathrm{k}_{12} \cdot \text { Dose }}{\mathrm{Vt}(\boldsymbol{\alpha}-\boldsymbol{\beta})}\left(\mathrm{e}^{-\beta \mathrm{t}}-\mathrm{e}^{-\alpha \mathrm{t}}\right)
$$

$\mathrm{Vt}$ : Tissue Compartment の分布容積

なお，小児患者の場合は， $\beta=0.69\left(\mathrm{~h}^{-1}\right)$ $=0.0115\left(\mathrm{~min}^{-1}\right)$ のかわりに, C S-1170 小 児科科領域研究会発表データ（1977～1978）に もとづいて算出した $\beta=0.85\left(\mathrm{~h}^{-1}\right)=0.0142$

結

\section{1. 抗菌力}

表 1 は耳翼咽喉科領域で分離された菌種, S. aureus, Streptococcus pyogenes, Streptococcus pneumoniae, Haemophilus influenzae

および Peptococcus spp., Peptostreptoccus spp., Bacteroides melaninogenicus $\mathrm{C}$ MZに対する感受性を示したものである ${ }^{9}$.

i ) S.aureus (124 strains)

$10^{8} \mathrm{CFU} / \mathrm{ml}$ におけるM I Cのピークは 1.56 $\left(\min ^{-1}\right)$ を用いた。

さらに, 従来より存在するセフェム系薬剤で ある Cefazolin（以下CE Zと略す）を用いて $0.5 \mathrm{~g}$ および $1 \mathrm{~g}$ one shot 静注の際の血清中 濃度および口蓋扁桃中濃度を測定した。

これらとは別に, 上顎洞粘膜 3 検体を用いて 組織内濃度測定におよぼす血液の影響をみるた めに組織より血液を除去しなかった例, 軽く除 去した例掞よび生理食塩液で洗浄した例につき 組織内濃度を測定し, 比較検討した。

果

$\mu \mathrm{g} / \mathrm{ml}$ を示した。 そして $\geqq 50 \mu \mathrm{g} / \mathrm{ml}$ の高いM I Cを示す株は 2 秼 (1.6\%) であった。一方, $10^{6} \mathrm{CFC} / \mathrm{ml}$ におけるM I C のピークは 0.78 $\mu \mathrm{g} / \mathrm{ml}$ であった。

ii ) S. pyogenes (86 strains)

$0.39 \mu \mathrm{g} / \mathrm{ml}, 0.78 \mu \mathrm{g} / \mathrm{ml}$ の 2 筒所に大部分の 株が集まる成績であった。

iii) S. pneumoniae (75 strains)

S. pyogenes とほば同様, $0.39 \mu \mathrm{g} / \mathrm{ml}, 0.78$

表 I 耳鼻咽喉科領域臨床分離菌株の CMZに対する感受性

\begin{tabular}{|c|c|c|c|c|c|c|c|c|c|c|c|c|c|c|}
\hline & \multirow{2}{*}{$\begin{array}{l}\text { Inoculum } \\
\text { size }\end{array}$} & \multicolumn{13}{|c|}{$\operatorname{MIC}(\mu \mathrm{g} / \mathrm{m} \ell)$} \\
\hline & & 0.1 & 0.1 & 0.2 & 0.39 & 078 & 1.56 & 3.13 & 6.25 & 12.5 & 25 & 50 & 100 & .100 \\
\hline \multirow{2}{*}{$\begin{array}{c}\text { Stuphylococcus aur'us } \\
\text { (124 strains) }\end{array}$} & $10^{8}$ & & & 2 & 5 & 46 & 51 & 16 & & 2 & & 2 & & \\
\hline & $10^{6}$ & & & 2 & 10 & 62 & 40 & 6 & 2 & & 2 & & & \\
\hline \multirow{2}{*}{$\begin{array}{l}\text { Streptecocecus pyogenes } \\
\text { (86 strains) }\end{array}$} & $10^{8}$ & & & 4 & 45 & 35 & 2 & & & & & & & \\
\hline & $10^{6}$ & & 2 & 6 & 46 & 32 & & & & & & & & \\
\hline \multirow{2}{*}{$\begin{array}{l}\text { Streptococecus pnerumoniur } \\
\text { (75 strains) }\end{array}$} & $10^{8}$ & & & 3 & 31 & 41 & & & & & & & & \\
\hline & $10^{6}$ & & 1 & 5 & 36 & 33 & & & & & & & & \\
\hline \multirow{2}{*}{$\begin{array}{c}\text { Haemopilus influenzae } \\
\text { (80 strains) }\end{array}$} & $10^{8}$ & & & & & & 10 & 26 & 37 & 5 & 2 & & & \\
\hline & $10^{6}$ & & & & & & 14 & 38 & 26 & 2 & & & & \\
\hline \multirow{2}{*}{$\begin{array}{l}\text { Peptococcus spp* } \\
\text { (56 strains) }\end{array}$} & $10^{8}$ & 2 & 7 & 17 & 11 & 13 & 4 & 2 & & & & & & \\
\hline & $10^{6}$ & 3 & 9 & 22 & 10 & 8 & 4 & & & & & & & \\
\hline \multirow{2}{*}{$\begin{array}{l}\text { Peptostreptococerus spp.* } \\
\text { (60 strains) }\end{array}$} & $10^{8}$ & & 4 & 9 & 10 & 18 & 13 & 6 & & & & & & \\
\hline & $10^{6}$ & & 6 & 10 & 14 & 16 & 10 & 4 & & & & & & \\
\hline \multirow{2}{*}{$\begin{array}{l}\text { Bacteroides melaminogenicus } \\
\qquad(24 \text { strains) }\end{array}$} & $10^{8}$ & 3 & 8 & 9 & 2 & & 2 & & & & & & & \\
\hline & $10^{6}$ & 4 & 8 & 10 & & 2 & & & & & & & & \\
\hline
\end{tabular}

* Peptococcus magnus: 19, Peptococcus prevotii: 14. Peptococcus asaccharolyticus: \&

Peptococcus constellatus: H. Peptococcus spp.: 11

* * Peptostreptococcus anaerobius: 16, Peptostreptococcus intermedius : 19. Peptostreptococcus spp.: 25 出口浩一他 J.J.A.投稿中9) より引用 
$\mu \mathrm{g} / \mathrm{ml}$ の 2 箇所に大部分の株が集まる成績であ った.

iv) $\mathrm{H}$. influenzae (80 strains)

$10^{8} \mathrm{CFU} / \mathrm{ml}$ で $6.25 \mu \mathrm{g} / \mathrm{ml}, 10^{6} \mathrm{CFU} / \mathrm{ml}$ で 3.13 $\mu \mathrm{g} / \mathrm{ml}$ に M I Cのピークを示した.

v) Peptococcus spp. (56 strains)

$10^{8} \mathrm{CFU} / \mathrm{ml}$ では $\leqq 3.13 \mu \mathrm{g} / \mathrm{ml}, 10^{6} \mathrm{CFU} / \mathrm{ml}$ は $1.56 \mu \mathrm{g} / \mathrm{ml}$ で $100 \% の$ 株の発育を阻止した. このうち $10^{6} \mathrm{CFU} / \mathrm{ml}$ で, $\leqq 0.39 \mu \mathrm{g} / \mathrm{ml}$ のきわ めて小さいM I Cを示した成績は78.6\%であっ た.

vi) Peptostreptococcus spp. (60 strains)

Peptococcus spp.の成績とほぼ同様の成績 であったが, $10^{6} \mathrm{CFU} / \mathrm{ml} て ゙ \geqq 1.56 \mu \mathrm{g} / \mathrm{ml}$ の中 等度のM I Cを示す株は $23.3 \%$ で, これらは

Peptococcus anaerobius であった。

vii) B. melaninogenicus (24 strains)

$10^{8} \mathrm{CFU} / \mathrm{ml}$ では, $\leqq 0.2 \mu \mathrm{g} / \mathrm{ml}$ で $83.3 \%$ の株 の発育を阻止した。

2. $\mathrm{CMZ}$ の臨床移行濃度における抗菌作用 臨床上病巣において予想される濃度での C M Zの抗菌作用を, E. coli, S. aureus の 2 種類 の菌を対象に調べた．S. aureus において，2 時間後までは刘照を除き，いずれのCMZ激度

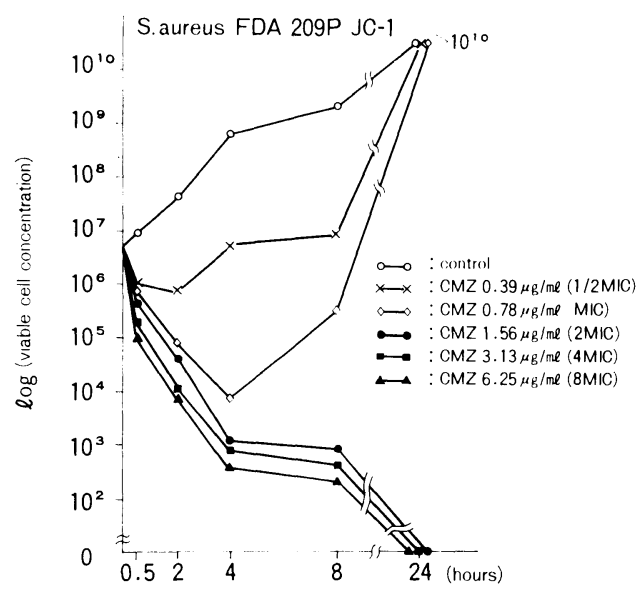

図 $2 \mathrm{CMZ}$ の臨床的移行濃度における抗菌作用 一経時的な生菌の消長 (M I C, M B C) について
においても, 濃度に比例した菌量の減少を認め た。 4 時間後では， $0.78 \mu \mathrm{g} / \mathrm{ml}$ ( 1 M I C ) 以 上の CMZ 濃度で菌量は $10^{4} \sim 10^{2}$ レベルまでの 範囲にて, CMZ 濃度に比例した菌量の減少を 認めた。 8 時間後では $1.56 \mu \mathrm{g} / \mathrm{ml}$ ( 2 M I C ) 以上の濃度では菌量はゆるやかな減少を示した

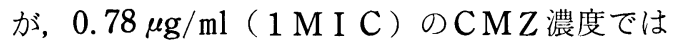
菌量は30分後とほぼ同量の $10^{5}$ レベルへと増加 し，以後増加を示した。24時間後および48時間 後の培養では, $1.56 \mu \mathrm{g} / \mathrm{ml}$ （2 M I C ）以上 の濃度に抢いては生菌は検出しなかった（図 2 ).

E. coli においても, S. aureus 之同様に 2 時 間目までは対照を除き, CMZ 濃度に比例した 菌量の減少を認めた。 4 侍間目では, $1.56 \mu \mathrm{g} /$

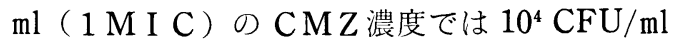
と菌量は減少した。 $3.13 \mu \mathrm{g} / \mathrm{ml}(2 \mathrm{M} \mathrm{I} \mathrm{C} \mathrm{)およ}$ び $6.25 \mu \mathrm{g} / \mathrm{ml}$ ( 4 M I C ) では生菌は検出しな かった. $0.78 \mu \mathrm{g} / \mathrm{ml}$ (1/2M I C ) 以下の濃度で は菌量は実験開始時の濃度あるいはそれ以上に 増加した。 8 時間目では, $1.56 \mu \mathrm{g} / \mathrm{ml}$ ( $1 \mathrm{M} \mathrm{I}$ C ) の濃度では菌量は $10^{3} \mathrm{CFU} / \mathrm{ml}$ と減少し た。 24 時間目および 48 㭙間目では， $3.13 \mu \mathrm{g} / \mathrm{ml}$ ( 2 M I C ), $6.25 \mu \mathrm{g} / \mathrm{ml}$ ( 4 M I C ) の浱度で

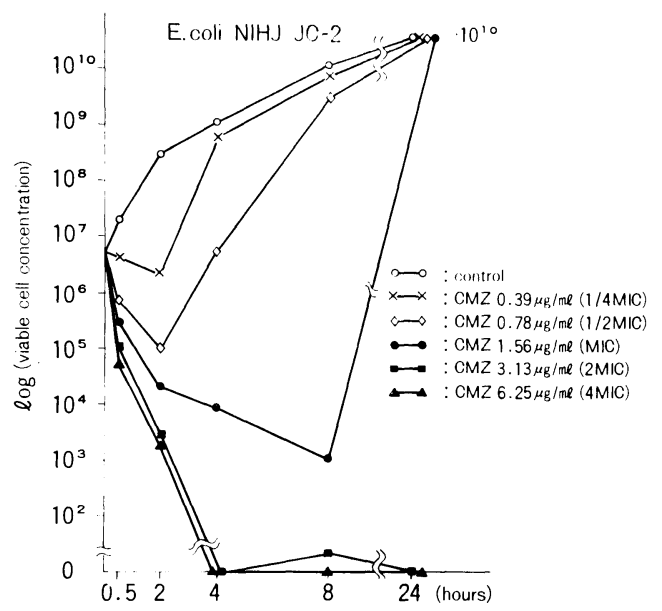

図 $3 \mathrm{CMZ}$ の臨床的移行濃度における抗菌作用 一経時的な生菌の消長 (M I C, M B C) について一 
は生菌を検出しなかった（図 3 ）。

以上より S. aureus, E. coli では, M I C

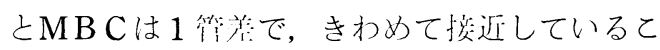
とがわかった。

\section{3 。組織内涉度}

闵 4 に，小児患者にCMZ $1 \mathrm{~g}$ 投与したとき の血清中濃度と扁桃中濃度を示した。投与後30 分の平均扁桃中濃度は $30.0 \mu \mathrm{g} / \mathrm{g}(\mathrm{n}=3)$ で あり，180分後にも $1.4 \mu \mathrm{g} / \mathrm{g}(\mathrm{n}=1)$ の力価 が検出された。これに対し，投与後30分の平均 血清中濃度は $124 \mu \mathrm{g} / \mathrm{ml}(\mathrm{n}=5)$ で，165分に あ $18.8 \mu \mathrm{g} / \mathrm{ml}(\mathrm{n}=1)$ であった。これら実測 值に対し, two compartment open model に より求めた simulation curve はよく一致し た.

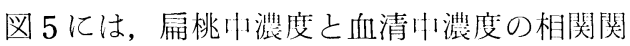
係を示した。乙の図には $1 \mathrm{~g}$ 投与例の他に, $2 \mathrm{~g}$ および $0.6 \mathrm{~g}$ 投与例屯併示したが, 陑桃中 濃度は血清中濐度の増大と対応して増大するこ とが予期された， $1 \mathrm{~g}$ 投与例と $2 \mathrm{~g}$ 投与例につ

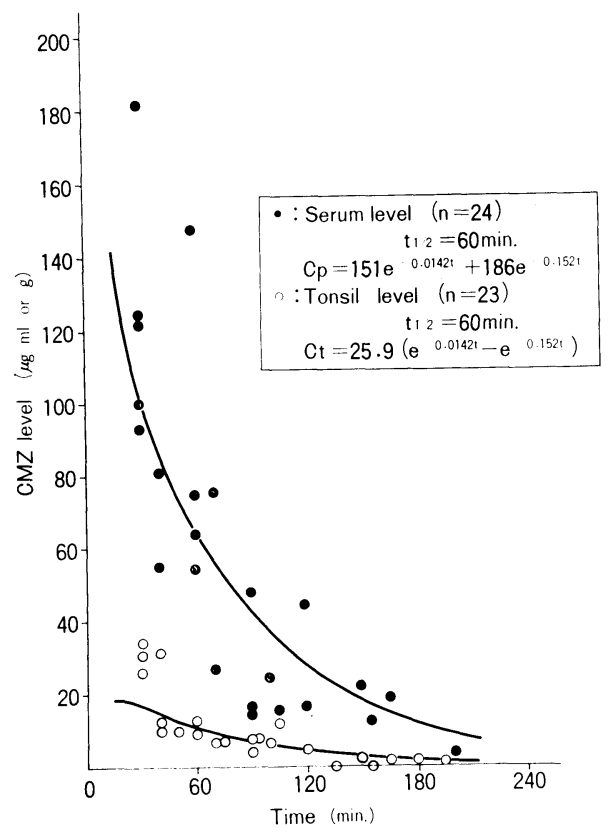

図 $4 \quad C M Z \quad 1 g$ 静注後の血清中および扁桃中 CM Z 濃度
いて求めた相関係数はそれぞれ $0.8585(\mathrm{n}=$ 19), $0.9188(\mathrm{n}=8)$ であり再濃度間には有

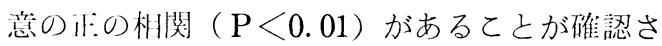
れた。

また両投与量での回㸉南線の勾配から CMZ の扁桃中濃度は血清中濃度の20〜 25\%程度と推 定された。実際に症例ごとの扁桃中濃度と血清 中浱度の比率（扁桃中移行率）在求め, 血清中 濃度に刘してプロットしたのが刻 6 である. 1 例を除きすべてが $10 \%$ 以上の移行率を示した が，大部分のものは10〜30\%の籁囲に集中し た。

次に, CMZの対照梖剂である C E Z の口蓋 阴桃小濃度を検捨した結果を表 2 亿示す。対象 は小児11例，成人 3 例の計 14 例であり， $0.5 \mathrm{~g}$ 投与例 6 例， $1 \mathrm{~g}$ 投与 8 例である.

需桃中濃度を対心する血清中浱度に対してプ ロットしたのが図 7 である。 $0.5 \mathrm{~g}$ 投与と $1 \mathrm{~g}$ 投与.での相関係数はそれぞれ0.9799，0.9219で あり, 両濃度間には有意な正の相関 $(\mathrm{P}<0.01)$

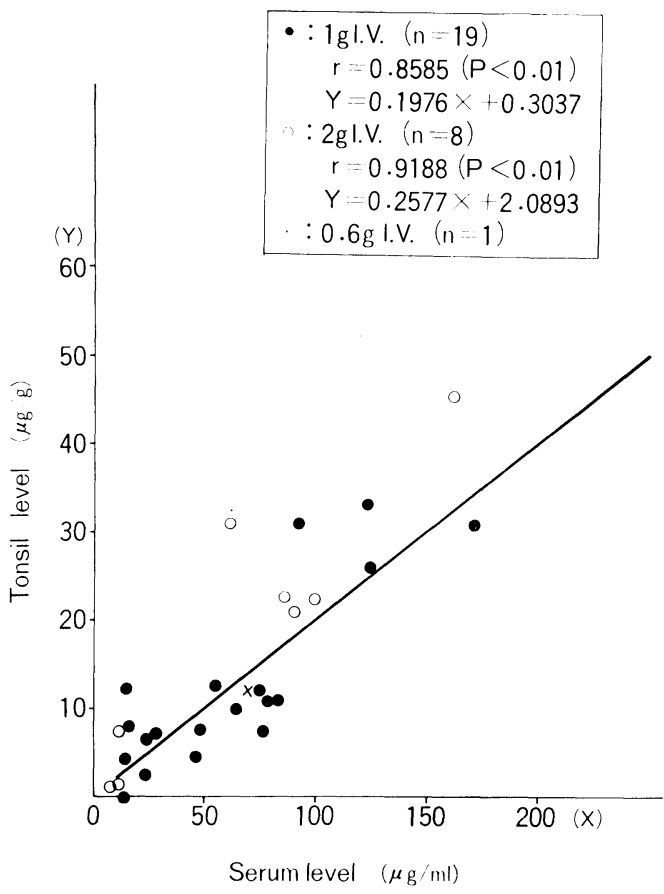

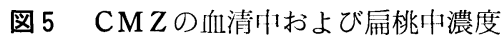




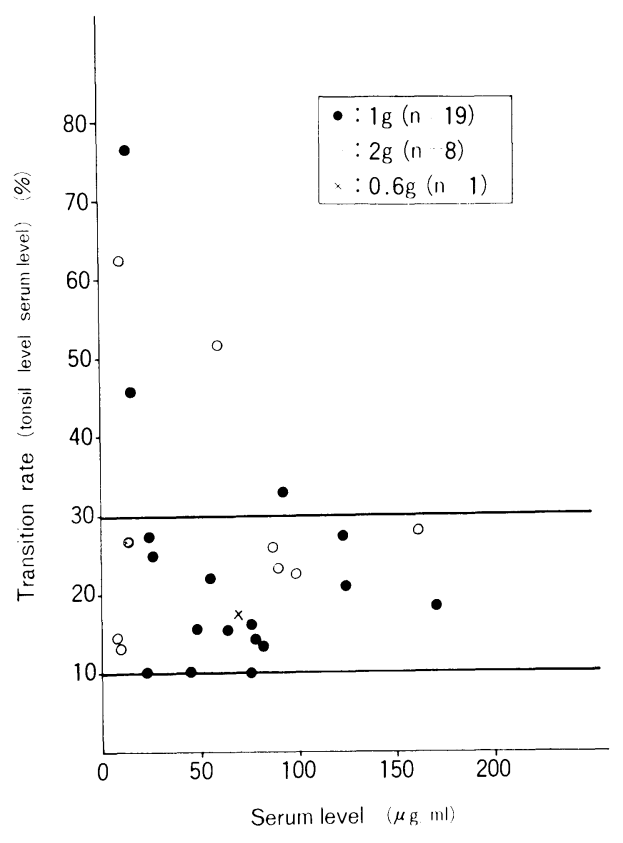

図 $6 \mathrm{CM} \mathrm{Z}$ 静注後の扁桃・血清中濃度比

表 2 C E Z の血中および扁桃中濃度

\begin{tabular}{|c|c|c|c|c|c|}
\hline \multirow{2}{*}{ 症 例(性) } & \multirow{2}{*}{$\begin{array}{l}\text { 年 } \\
\text { 命 }\end{array}$} & \multirow{2}{*}{ 投与量 } & \multirow{2}{*}{$\begin{array}{c}\text { 採取時点 } \\
\text { (InII.). }\end{array}$} & \multicolumn{2}{|c|}{ CEZ濃度 $(/ \mathrm{g} / \mathrm{m} \ell)$} \\
\hline & & & & 血清 & 扁 桃 \\
\hline A.M. $(\because)$ & 6 & $0.5 \mathrm{~g} . \mathrm{t.V}$ & 25 & 63.0 & 7.4 \\
\hline A.H.(') & 6 & " & 20 & 148.0 & 21.0 \\
\hline S.Y.(') & 8 & 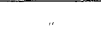 & 120 & 41.8 & 6.8 \\
\hline$K \cdot K \cdot(:)$ & 6 & $"$ & 75 & 53.5 & 8.5 \\
\hline O.A. (') & 9 & & 70 & 36.7 & 7.4 \\
\hline N.T. ( $)$ & 9 & " & 90 & 30.5 & 4.4 \\
\hline T.S.(i) & 19 & 1.0g. I.v. & $\begin{array}{l}25 \\
37\end{array}$ & $\overline{72.0}$ & $\begin{array}{c}23.8 \\
-\end{array}$ \\
\hline S.K.(1) & 8 & " & 20 & 178.0 & 33.2 \\
\hline K.M. (.) & 11 & & 40 & 63.0 & 11.8 \\
\hline S.T. (') & 8 & " & 65 & 75.5 & 12.1 \\
\hline$k . K .(:)$ & 6 & " & 33 & 75.5 & 23.7 \\
\hline$M \cdot N \cdot(:)$ & 13 & $"$ & $\begin{array}{l}60 \\
75\end{array}$ & $\begin{array}{l}40.5 \\
-\end{array}$ & $\begin{array}{l}5.1 \text { (右) } \\
5.8 \text { (左) }\end{array}$ \\
\hline Y.T.(i) & 48 & $"$ & 100 & 38.0 & 6.6 \\
\hline O.T. (:) & 34 & " & 80 & 38.0 & 0.1 \\
\hline
\end{tabular}

が垫められた。耐投与量での回师式の勾配か ら, C E Z の扇桃川移行率は13〜20\%程度と推 定される。症例ごとに求めた C E Z の扁桃け移

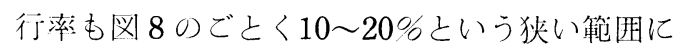
集川している.

ここで， C E $Z$ と CMZとを小児に対し $1 \mathrm{~g}$ 投与し，それぞれ，40分値，60分值を測定した 症例につき比較してみる，40分值では，表 2 の 如く, C E Zの扁桃中濃度は $11.8 \mu \mathrm{g} / \mathrm{g} （ \mathrm{n}=$ 1 ）であった。一j, CMZの40分值は 3 例に

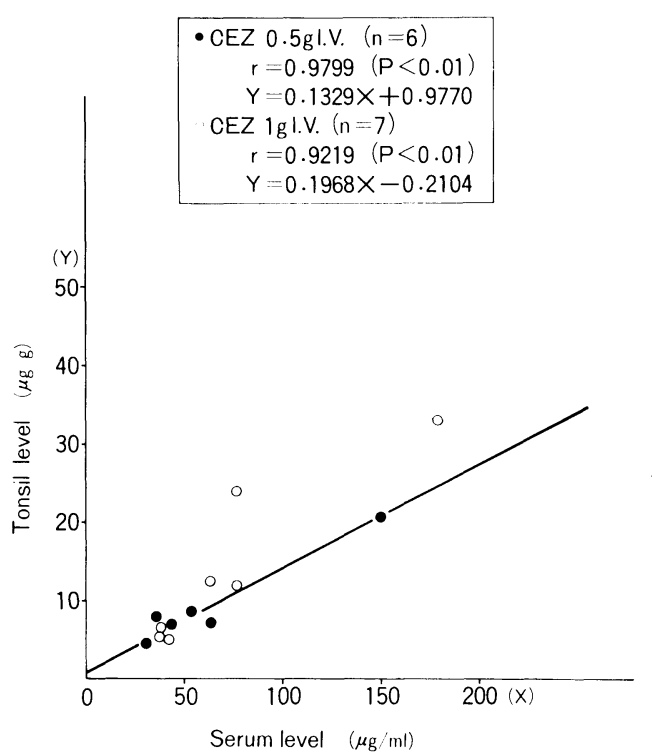

図 7 C E Z の血清中および扁桃中濃度

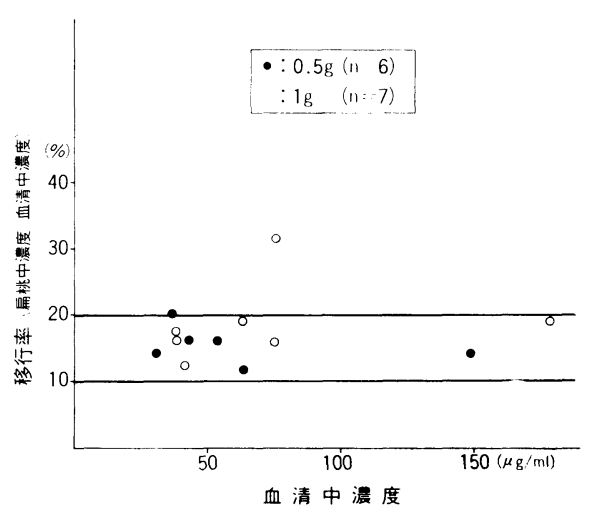

图 8 C E Z 静注後の扁桃・血清中濃度比 
て, $10.9 \mu \mathrm{g} / \mathrm{g}, 12.2 \mu \mathrm{g} / \mathrm{g}, 31.1 \mu \mathrm{g} / \mathrm{g}$ を示 した（図4）。また，60分值では， CEZは $5.1 \mu \mathrm{g} / \mathrm{g}(\mathrm{n}=1)$ であり, CMZは 2 例にて $10.0 \mu \mathrm{g} / \mathrm{g}, 12.1 \mu \mathrm{g} / \mathrm{g}$ であった。以上より, 2 剂の口蓋扁桃中濃度はほぼ近似した值を示し た。

成人患者にCMZ $2 \mathrm{~g}$ を投与したときの血清 中濃度と上顎洞粘膜中濃度を図 9 亿示した。投 与後 30 分の平均上顎洞粘膜中濃度は $43.4 \mu \mathrm{g} / \mathrm{g}$ $(\mathrm{n}=5)$ で 210 分後にあ $2.9 \mu \mathrm{g} / \mathrm{g} \quad(\mathrm{n}=1)$ の濃度が検出された。一方, 投与後 30 分の平均 血清中濃度は $105 \mu \mathrm{g} / \mathrm{ml}(\mathrm{n}=11)$ で270分後で 屯 $6.9 \mu \mathrm{g} / \mathrm{ml}(\mathrm{n}=1)$ の濃度を示した。とれら 実測值に対し two compartment open model により求めた simulation curve はよく一致し た。 上顎洞粘膜中濃度と血清中濃度の間にも 図10の如く有意な正の相関（ $\mathrm{p}<0.05 ）$ が見ら れたが，プロットのバラッキは扁恌の場合より 大きかった，扁桃について行なったと同様に症 例ごとの CMZの上顎洞粘膜への移行率〔（上 顎洞粘膜中濃度 $/$ 血清中濃度 $) \times 100 〕$ を求め

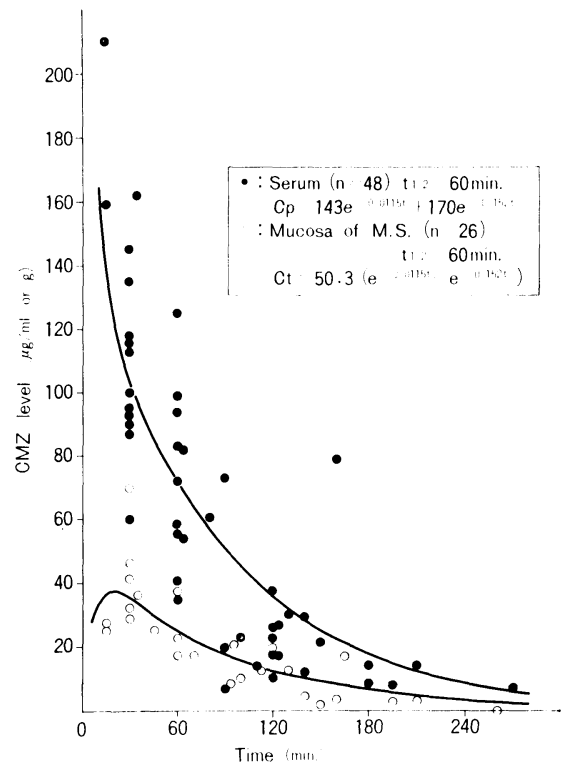

図 $9 \mathrm{CMZ} 2 \mathrm{~g}$ 静注後の血清中および上顎洞粘膜中 濃度
血清中濃度に対してプロットしたのが図11であ る. 移行率が $4 \%$ 以下のものはなかったが，大 部分は15〜45\%という広い範囲に分布した。

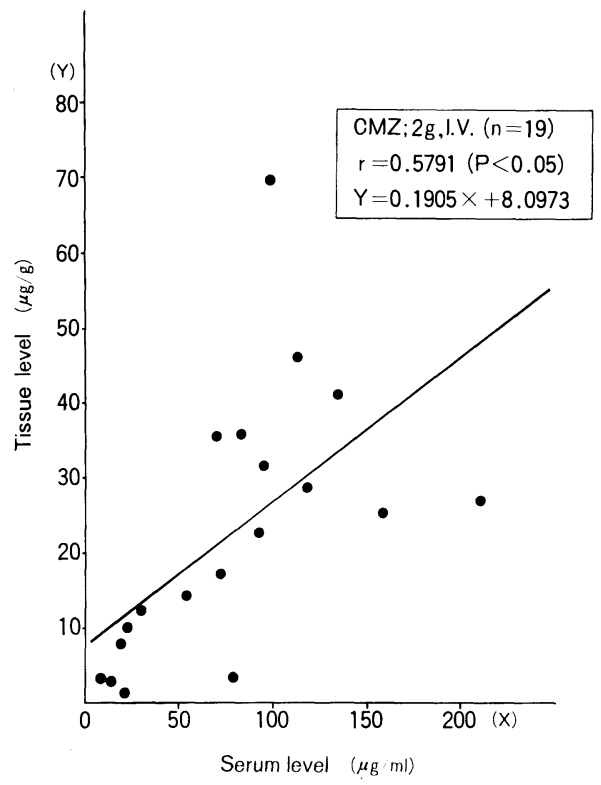

図10 CMZ $2 \mathrm{~g}$ 静注後の血清中および上顎洞粘膜中 濃度

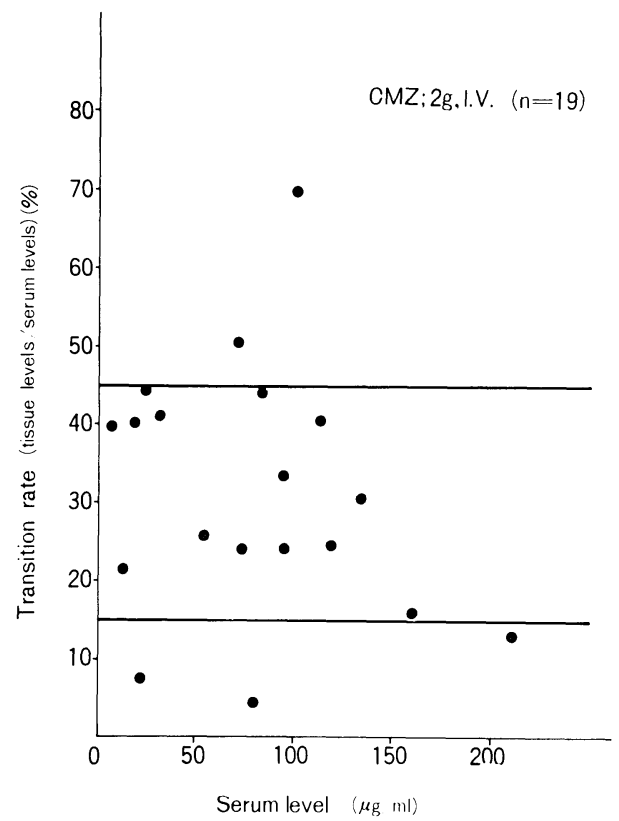

図IICMZ $2 \mathrm{~g}$ 静注後の上顎洞粘膜 - 血清中濃度比 
考

感染症の治療において抗生物質の果す役割 は, 感染病棵で起炎菌に対して十分な抗菌力を 発揮するこ亡にある。

耳鼻咽喉科領域, 特に上気道では, 検体採取 時に, 定着常在細菌叢の混入が避けられないこ とが多い。そのため, 日常診療において起炎菌 の同定には熟慮が必要であり, 抗生物質の使用 にあたっては，起炎菌の感受性を考慮した上 に，組織移行性および副作用を屯考え合せて， 適切な抗生剂を使生するととが望ましい.

この観点から，まず定着常在細菌叢ついて 考察を加えたい.

はじめに, 正常常在細菌叢を考える一助とし て, 出口 ${ }^{10)}$ の健康成人の涶液加ら分離した細菌 叢に関する報告がある（表 3 ）。

それによると, 健常時に有意に常在細菌叢を 構成している菌種としては，嫌気性菌の方が量 的には多いが，好気性菌もかなりの位置を占 めている。好気性で有意に定着的に常在して いる菌種としては, $\alpha$-streptococcus, $\gamma$ -

表 3 健常応人の睡液から分離した細菌對 (好気性菌) -40 名一

\begin{tabular}{|c|c|c|}
\hline 菌 & 分離䫢度 (\%) & 菌数 $/ \mathrm{m} \ell(\log )$ \\
\hline Staphylococcus aureus & 10 & $2 \sim 3$ \\
\hline Staphylococcus epidermidis & 65 & $3 \sim 5$ \\
\hline Micrococcus spp. & 20 & $2 \sim 4$ \\
\hline Aerococcus viridans & 15 & $2 \sim 4$ \\
\hline$\alpha$-streptococcus & 100 & $5 \sim 7$ \\
\hline 3-streptococcus (group A) & 2.5 & 2 \\
\hline$" \quad($ group B ) & 10 & $2 \sim 3$ \\
\hline$" \quad$ (others) & 5 & $2 \sim 3$ \\
\hline$\gamma$-streptococcus & 85 & $3 \sim 5$ \\
\hline Streptococcus group $D^{*}$ & 60 & $3 \sim 4$ \\
\hline Streptococcus pneumoniae & 25 & $2 \sim 3$ \\
\hline Corynebacterium spp. & 70 & $4 \sim 5$ \\
\hline Lactobacillus spp. & 25 & $4 \sim 5$ \\
\hline Bacillus cereus & 35 & $2 \sim 3$ \\
\hline Haemophilus parahaemolyticus & 85 & $2 \sim 4$ \\
\hline Haemophilus parainfluenzae & 70 & $2 \sim 4$ \\
\hline Haemophilus influenzae & 15 & $3 \sim 4$ \\
\hline Neisserio spp. & 100 & $5 \sim 6$ \\
\hline glucose-fermentative GNR & 45 & $2 \sim 3$ \\
\hline glucose-nonfermentative GNR & 10 & $2 \sim 3$ \\
\hline yeast-like organism & 37.5 & $2 \sim 3$ \\
\hline
\end{tabular}

察

streptococcus, Corynebacterium spp. (C. diphteriae 除く), Staphylococcus epidermidis, Streptococcus group D (Enterococcus group), Neisseria spp. (N.meningitidis を除く), Haemophilus parahaemolyticus な どがあげられている。

出口 ${ }^{11)}$ はまた, 1977年 6 年〜1979年 5 月まで の 2 年間で東京総合臨床検査センターに提出さ れた検体のうち，主として扁桃炎，上咽頭炎の 0 歳㫛から高秢者までの患者試料から検出した 菌の分布を報告している（表 4 ）.

出口 ${ }^{11)}$ にると, 㻞桃部加の検出菌は $\beta$ streptococcus group A, B 等が 1,096症例中 632 症例で $57.7 \%$, S. aureus が $13.4 \%$, S. pneumoniae が $7.5 \%$ で，乙れらを合わせると $78.6 \%$ となり，グラム陽性球菌が約 8 割を占め るととになる。

同じく, 出口 ${ }^{10)}$ は鼻・副鼻腔炎患者材料から の検出菌についても報告している（表 5 ）。乙

表 4 上気道感染症患者検出菌

1977. $6 \sim 1979 . \quad 5$

\begin{tabular}{|c|c|c|c|c|}
\hline \multicolumn{2}{|c|}{ 扁桃部採取粘液 } & \multirow{2}{*}{$\frac{\text { 分離菌株名 }}{\text { Staphylococcus aureus }}$} & \multicolumn{2}{|c|}{ 上咽頭部採取粘液 } \\
\hline 147 株 & $10.5 \%$ & & 36 株 & $11.1 \%$ \\
\hline 18 & 1.3 & Staphylococcus epidermidis & 5 & 1.5 \\
\hline 4 & 0.3 & Micrococcus spp. & 3 & 0.9 \\
\hline 580 & 41.3 & S-streptococcus (group A) & 24 & 7.4 \\
\hline 37 & 2.6 & $" \quad$ (group B) & 5 & 1.5 \\
\hline 15 & 1.1 & (others) & 2 & 0.6 \\
\hline 82 & 5.8 & Streptococcus pneumoniae & 88 & 27.2 \\
\hline 139 & 9.9 & Haemophilus influenzae & 68 & 21.0 \\
\hline 40 & 2.9 & Haemophilus parainfluenzae & 11 & 3.4 \\
\hline 8 & 0.6 & Haemophilus spp. & 4 & 1.2 \\
\hline 11 & 0.8 & Escherichio coli & 2 & 0.6 \\
\hline 3 & 0.2 & Citrobacter spp. & 0 & 0 \\
\hline 37 & 2.6 & Klebsiella pneumoniae & 8 & 2.5 \\
\hline 5 & 0.4 & Klebsiella spp. & 2 & 0.6 \\
\hline 46 & 3.3 & Enterobacter spp. & 15 & 4.6 \\
\hline 15 & 1.1 & Serratio marcescens & 7 & 2.2 \\
\hline 4 & 0.3 & Proteus spp. & 1 & 0.3 \\
\hline 42 & 3.0 & Pseudomonas aeruginosa & 4 & 1.2 \\
\hline 8 & 0.6 & Pseudomonas spp. & 1 & 0.3 \\
\hline 17 & 1.2 & Acinetobacter calcoaceticus & 6 & 1.9 \\
\hline 52 & 3.7 & anaerobes & 0 & 0 \\
\hline 30 & 2.1 & yeast-like organism & 10 & 3.1 \\
\hline 63 & 4.5 & others & 22 & 6.8 \\
\hline 1,403 & 100.0 & 計 & 324 & 100.0 \\
\hline
\end{tabular}


表 5 鼻・副鼾腔炎患者採取材料から検出菌

1678. $7 \sim 1980.6$

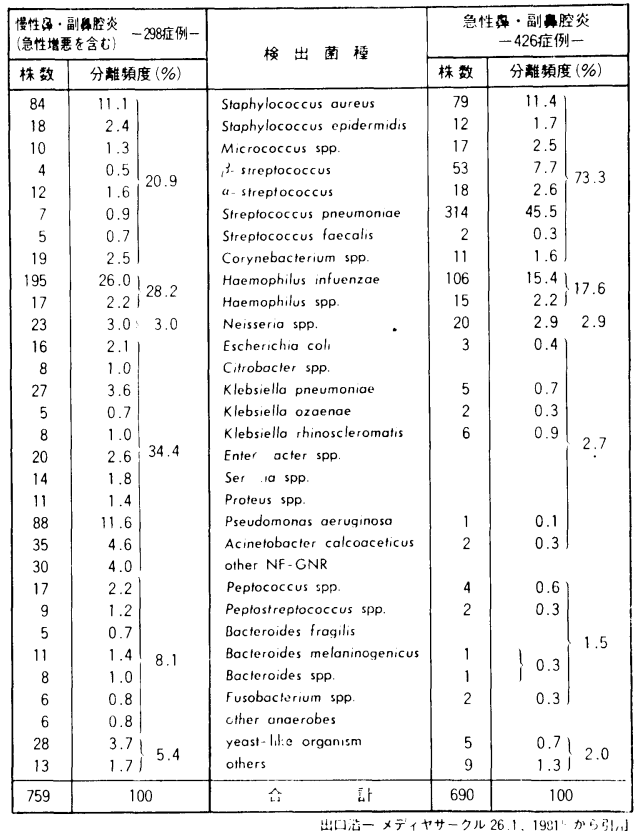

れらの報告は実地臨床医家から提出される検体 についてのものがほとんよ゙であり，いわゆる primary care を行っている施設のデータを示 している.

急性鼻・测鼻腔炎患者の検体からは，426症 例から S. pneumoniae が 314株検出され, 検 出率 $73.6 \%$ （注: : 表の\%は分離総株数比, 以下 文中は症例分離比，つまり条々の藏が検出され るチャンス）と压倒的に多く, ついで H. inf1uenzae $24.9 \%$, S. aureus $18.5 \%, \beta$-streptococcus (group A, G etc.) 12.4\%などで ある。

S. pneumoniae, S. aureus, $\beta$-streptococcus は単独検出例が多く, H. influenzae は他䒩種 (特に, S. pneumoniae) との混在例が大部分 を占めている.

慢性鼻・测鼻腔炎では Pseudomonas aeruginosa $29.5 \%$, S. aureus $28.2 \%$, Klebsiella pneumoniae などの晹内細菌科のグラム㓌性悍 菌, 線脹菌以外のブドウ糖非:発酵性グラム隆性
表 6 Bacteria isolated from ma :illary sinus

\begin{tabular}{|c|c|c|}
\hline Organism & No.of strains & $\%$ \\
\hline Staphylococcus aureus & 8 & 7.1 \\
\hline Staphylococcus epidermidis & 14 & 12.4 \\
\hline Streptococcus pneumoniae & 11 & 9.8 \\
\hline Streptococcus haemolyticus & 14 & 13 \\
\hline Haemophilus influenzae & 19 & 16.9 \\
\hline Haemophilus parainfluenzae & 1 & 0.8 \\
\hline Corynebacterium (aerobic) & 2 & 1.8 \\
\hline Pseudomonas aeruginosa & 6 & 5.3 \\
\hline Pseudomonas cepacia & 2 & 1.8 \\
\hline Pseudomonas maltophilia & 1 & 0.8 \\
\hline Klebsiella & 1 & 0.8 \\
\hline Serratia & 3 & 2.7 \\
\hline Proteus mirabilis & 1 & 0.8 \\
\hline Peptostreptococcus & 8 & 7.1 \\
\hline Peptococcus & 2 & 1.8 \\
\hline Veillonella & 2 & 1.8 \\
\hline Bacteroides & 1 & 0.8 \\
\hline Propionibacterium & 3 & 2.6 \\
\hline Lactobacillus & 4 & 3.5 \\
\hline Microaerophilic streptococci & 10 & 8.5 \\
\hline Total & 113 & 100 \\
\hline
\end{tabular}

悍菌(NF-GNR)，また，嫌気性菌もかなり検出 される，このうち，S. aureus が検出される堤 合は，単独検出例が多く，急性増覀剘としての 倾向を示すが，グラム陰性悍䒩 (H. influenzae を除く）や嫌気性䒩が検出される場合は複数菌 の混在例が多く，複彩な様相を示す嵒休例が大 部分を上めている。

一j, 著者ら ${ }^{121}$ が行なった，上顎润穿刺を行

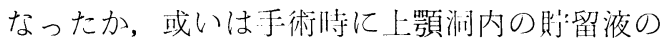
細莉培鸴を行なった症例での検出菌を表 6 亿示 した.

好気性菌では，H. influenzae 16.9\%, Streptococcus haemolyticus $13 \%$, S. epidermidis $12 \%$, S. pneumoniae $9.8 \%$, S. aureus 7.1\%などであり，他に，P. aeruginosa $5.3 \%$ などが比較的高い検出率をらぬた。

また，嫌気性菌では Microaerophilic streptococci $8.5 \%$, Peptostreptococcus $7.1 \%$ ごが主な検出菌であった。なお，㨽鼻腔炎より の嫌気性藏検出率は，想啰 ${ }^{13)} 15.1 \%$ ，栗(以 ${ }^{14)}$ 
$28.6 \%$ ，著者ら ${ }^{12)} 26 \%$ あった。また，嫌気 性菌が単独に検出された症例屯，照場 ${ }^{13)} 5.4 \%$ , 著者ら ${ }^{12)} 10 \%$ と比較的高率であった。

以上は卌桃炎, 鼻・副鼻腔炎での検出菌の文 献的考察である.

次に, 耳鼻咽喉科領域での抗生物質の組織移 行に関するいままでの報告と今回の著者らの成 績と比較検討したい.

セファロスポリン抗生剤では, C E Z 亿関し , 高須 ${ }^{1)}$ ら, 三好 ${ }^{21}$, 岩沢 ${ }^{3)}$ の報告があり, 著 者らも前述の如く，14例につき，CE Z の口蓋 扁桃中濃度を測定した。

いずれの研究者む投与量および投与才法は異 なる屯のの, 血清中濃度, 口蓋扁桃中濃度, 上 顎洞粘膜中濃度を測定している.

扁桃中濃度：高須ら ${ }^{1)}$ は成人に C E Z $250 \mathrm{mg}$ および $500 \mathrm{mg}$ の筋注を行ない，投与 1 時間後に それぞれ平均 $3.4 \mu \mathrm{g} / \mathrm{g}(\mathrm{n}=3), 7.6 \mu \mathrm{g} / \mathrm{g}$

$(\mathrm{n}=3)$ の濃度を検出している。岩沢3) は $500 \mathrm{mg}$ 筋注 6 例につき報告している。平均では, 筋注 1 時間後にて, 組織内濃度 $7.1 \mu \mathrm{g} / \mathrm{g}$, 血 清中濃度 $13.3 \mu \mathrm{g} / \mathrm{ml}$ であり, 組織移行率は $53 \%$ であった。 三好ら 2)は，15例にCE Z $2 \mathrm{~g}$ を点 滴静注し, 投与 25 分後より, 2 時間14分後まで 検舎した。三好ら ${ }^{2)}$ にると，血清より組織へ の移行率は $1.1 \%$ 52.2\%であり，10３0\%の 範囲に集中した。

一方, 著者らが C E Z 投与後測定した口蓋扁 桃中濃度は表 2 に示した。乙れと図 4 に示した CMZの值を比較すると，40,60分值で，ほぼ同 じ值を示した。さらに，血清より口蓋扁佻への 移行率について検討すると，C E Z は10〜20\% の範囲に分散し（図 8)。CMZは10〜30\%の 範囲に分散した（図6 )。㓰者を比較すると, CMZ に比し C E Z はバラッキが少なかった。

上顎洞粘膜中濃度 : 高須ら ${ }^{1)}$ の報告では, C $\mathrm{E} Z$ 投与 1 時間後にて, $250 \mathrm{mg}$ 筋注: 3 例では, 平均 $1.5 \mu \mathrm{g} / \mathrm{g}, 500 \mathrm{mg}$ 筋注 3 例では, 平均 3.5 $\mu \mathrm{g} / \mathrm{g}$ であった。岩沢 ${ }^{3)}$ は C E Z 500mg 筋注 3 例 において, 投与 1 時間後では, 組織内瀑度平均
$3.3 \mu \mathrm{g} / \mathrm{g}$, 血清中濃度平均 $11.7 \mu \mathrm{g} / \mathrm{ml}$ と報告 している. 三好ら ${ }^{2)} は, 2 \mathrm{~g} 30$ 分間の点滴静注 後58分, 1 時間 3 分の組織内濃度はそれぞれ $77,100 \mu \mathrm{g} / \mathrm{g}$ であり, 7 例で 34.9〜85.5\%と 高い組織移行率を報告している.

著者らがCMZを用いて行なった結果と比較 すると，口蓋扁桃中濃度でも，また血清より口 蓋㻞桃組織への移行率に関しても C E Z とほぼ 類似した值を示した。 上顎洞粘膜への移行で は, 著者らの成績は岩沢, 高須らの成績とほぼ 近似した值を示した。三好らの報告では, 高須

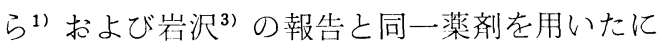
も拘らず，上顎润粘膜中濃度が前二者に比し大 であった。この原因として例えば注射剂の投与 経路の違いや, 組織に付着する血液の処理の問 題などが考えられる.

上顎洞粘膜は組織が小さいのでてれに血液が 付着すれば測定值に与える影響む大きい.

著者らは手術時採取した上顎洞粘膜に関し, ほぼ同一の検体量を一方は洗浄せず，ガーゼに て輅く血液を除去し, 他方は, 十分な生理食塩 液中で軽く洗浄し血液を除去し, その組織内C $M Z$ 濃度を測定し, 前処置の違いによる組織内 濃度を比較検封し, 結果を表 7 に示した。血清 より上顎润粘膜へのCMZの移行率について比 較するに, 洗洋前の上顎洞粘膜中濃度は63\%〜

表 $7 \quad C M Z 2 g$ 静注後の血清中および上顎洞粘 膜中濃度

\begin{tabular}{|c|c|c|c|c|}
\hline \multirow{3}{*}{ 症 例 } & \multirow{3}{*}{$\begin{array}{c}\text { 投与後の } \\
\text { 時 間 } \\
(\min .)\end{array}$} & \multicolumn{3}{|c|}{$\mathrm{CMZ}$ 濃度 $(\mu \mathrm{g} / \mathrm{m} \ell$ or $\mathrm{g})$} \\
\hline & & \multirow{2}{*}{ 血清 } & \multicolumn{2}{|c|}{ 上顎洞粘膜 } \\
\hline & & & 洗浄前 & 洗浄後* \\
\hline $\begin{array}{l}1 . \mathrm{K} . \mathrm{T} \\
30 \mathrm{yrs}, \quad+\end{array}$ & 90 & 19.2 & $\begin{array}{l}30.6 \\
(160)^{*}\end{array}$ & $\begin{array}{l}7.65 \\
(40)\end{array}$ \\
\hline $\begin{array}{l}2 . T . S . \\
44 y r s, \hat{\delta}\end{array}$ & 195 & 8.1 & $\begin{array}{l}6.2 \\
(77)\end{array}$ & $\begin{array}{l}3.24 \\
(40)\end{array}$ \\
\hline $\begin{array}{l}3 . \mathrm{T} . \mathrm{S} . \\
18 \mathrm{yrs} \text {, }\end{array}$ & 60 & 23.0 & $\begin{array}{l}14.7 \\
(63)\end{array}$ & $\begin{array}{l}10.2 \\
(44)\end{array}$ \\
\hline
\end{tabular}

*: 粘膜の採取の際に生理食塩水で洗浄したことを示す。

※：括弧内の数值は血清より上頴洞粘膜への移行率 $(\%)$ を 表わす。 
$77 \%, 160 \%$ とバラツキを示したが, 生理食塩 液中にて洗浄した例では $40 \sim 44 \%$ 移行率であ りほぼ一定值を示した。上顎洞粘膜中濃度は組 織型により差を生じると思われるが，口蓋扁桃 中濃度に比し一般に少量を測定に用いる傾向に あるので，上記のデータを考えあわせると測定 前に生食にて洗浄するなど一定の前処置を加え ることが好ましいと考えられる。

また，他の楽剤の組織移行に関して耳鼻咽喉 科領域における報告には，岩沢4) の Aminobenzyl Penicillin (ABPC), 三吉 ${ }^{5}$ らの Sulfobenzyl-Penicillin (SBPC), 守安 ${ }^{6)}$ の ABPC, Methylchlorophenylisoxazolyl, penicillin (MCI-PC), Aminodeoxykanamycin (AKM) についてのものがある.

なお，今回 S.aureus および E. coli を用 いて行ったM I C，MBCに関する実験におい て, M I C以上の CMZ 濃度においては，4 時 間目までは直線的に菌数の減少を認めた。いま までに，ある 1 株からいくつかのコロニ一を分 離し楽剂感受性を測定すると，その感受性は均 一ではないとの報告 ${ }^{15)}$ はいくつかある.
生体では, 薬剤は最高濃度に達した後, 次第 に排泄され，濃度は減少していく，今回の検討 から CMZ 投与後扁桃中濃度と上顎洞粘膜中濃 度は図 4 と図 9 の如く推移することがわかっ た。それらと, 図 2 , 図 3 に示した $1.56 \mu \mathrm{g} / \mathrm{ml}$ がM I Cである菌の場合には，加藤ら ${ }^{15)}$ や藤 井 ${ }^{16)}$ の言うように, $1.56 \mu \mathrm{g} / \mathrm{ml}$ の周囲の值がM I Cである菌が存在しても, $1.56 \mu \mathrm{g} / \mathrm{ml}$ の C M $Z$ 濃度が組織内に 4 時間は保たれるため, 生体 の防御作用屯あり, in vitroの実験以上に菌数 は減少するかもしれない。また，1/2M I Cの濃 度にても, 実験では 2 時間は菌の増加を阻止し ている。乙れにより, 今回と同様の組織内濃度 を保つのなら， M I Cが 1.56 あるいは 3.13 $\mu \mathrm{g} / \mathrm{ml}$ の菌に対しては約 6 時間は楽剂が有効に 作用するすのと思われる。

以上，今回著者らの行なった実験抢よび臨床 分離頻度の高い菌に対する C M Z OM I C は, $3.13 \mu \mathrm{g} / \mathrm{ml}$ 以下のむのがほとんどであり，乙れ ら疾患に今回の投与量にて治療を行なうのな ら, CMZはM I C とMBCが接近し, 殺菌的に 作用することからも，有效な楽剤と思われた。

\section{ま と め}

上気道炎に対する新セフェム系抗生剂 CMZの有用性につき，基礎的に検討を加えた。

(1)薬郕感受性では，上気道炎での分離頻度の高いS. aureus, $\beta$-streptococcus, S. pneumoniae, H. influenzae に対するM I Cは良好であった。

(2)グラム陰性桿菌，グラム陽性球菌の一例としてそれぞそ E. coli, S. aureus についてM I C と MB C を調べたとてろ，M I C とMB C は接近しており，良好な殺菌作用が期待できる.

(3)組織内濃度について血清中より，組織への移行率でみると，血清中濃度に関係なく口蓋扁桃組 織では，10３0\%に集中した．CE Zでは，10～20\%に集中し，CMZの場合よりバラッキが少な かった，乙れに対し，上顎洞粘膜組織ではCMZの移行率は15〜45\%の範囲に集中した.

以上より CMZは上気道炎に対しては有用な薬剂と思われる.

稿を終るにあたり，終始御世話いただいた三共株式会社学術部中村康夫氏に深謝いたします。

\section{文}

1) 高須照男, 他 : 耳鼻咽喉科領域におけるCefazolin の基礎的ならびに臨床的検討. Chemotherapy： $18: 5 ; 836 \sim 843,1970$.

2 ) 三好豊二, 他：セファメジン点滴時の組織内濃度
：耳鼻臨床 $73 ： 11 ； 1719 \sim 1727 ， 1980$.

3 ）岩沢武彦：Cefazolin 亿関する基礎的；臨床的研 究. Chemotherapy : 18; 5, 812 825, 1970.

4 ) 岩沢武彦: Aminobenzyl Penicillin の抗菌力吸 
収, 排泄ならびに組織移行に関する研究. 耳鼻臨 床 $63: 4 ; 413 \sim 422,1970$.

5 ) 三吉康郎, 他 : Sulfobenzyl-Penicillin の慢性 副鼻腔炎粘膜ならびに慢性扁桃炎組織移行に関す る研究. 耳鼻臨床 $67 ： 9 ; 889 \sim 894 \sim 1974$.

6 ）守安靖廉, 他：抗生剂の血中及び鼻腔・副鼻腔粘 膜組織内濃度に関する 2,3 の知見. 耳鼻臨床 $66: 4 ; 443 \sim 482,1973$.

7 ）真下啓明, 他：C S-1170亿関する基礎的・臨床 的研究. Chemotherapy $26: 5 ; 193 \sim 202$, 1978.

$8 ）$ M I C 測定法改訂委員会：最小発育阻止濃度（M I C) 測定法再改訂について. Chemotherapy $29: 76 \sim 79$, 1981.

9 ）出口浩一, 他: 耳鼻咽喉科臨床分離菌株に対する 第二世代セフェム系剤の感受性. J . J . A . : 投 稿中.

10）出口浩一：primary infection を主とした患者か ら検出される細菌の様相一検出される菌種の特徵 についてーその 1. メディヤ・サークル 26: 1 ; $1 \sim 8,1981$.

11）出口浩一：primary infection を主とした患 者から検出される細菌の様相一検出される菌種の 特徴について一その 3 .メディヤ・サークル 26 : $5 ; 31 \sim 36,1981$.
12）藤巻豊, 他：上顎洞炎の検出菌について第11回嫌 気性菌感染症研究会講演記録. エー 将 (1980), pp. $43 \sim 45$.

13) S. Baba : Anaerobic barteria isolated from chronic nasal sinusitis. In "Clinical Significance of Non-Sporeforming Bacteria in Clinical Bacteriology" Sym. No.40, Jpn. Soc. Microbiol., p. 44, Nagoya City, Japan, 1966.

14）栗山一夫：耳鼻咽喉科領域の病巣，とくに副鼻腔 炎における無牙胞偏性嫌気性菌についての検討. Chemotherapy $27 ; 5 ; 760 \sim 765,1979$.

15）加藤博, 他：Cefalothin Sodium の殺菌効果 (第 2 報) - Cefalothin Sodium の血中濃度に 3 回 simulate した in vitro model system に よる E. coli 3 株の生菌数変化および感受性に関 する population analysis 一. 最新医学 35 : $9 ; 1887 \sim 1894,1980$.

16）藤井良知 III. : 抗菌剂その 1 . 小児呼吸器感染症 と合成ペニシリン一なぜペニシリンは昔ほど効か ないのか一. 胸部疾患：8：；8，1043～1052, 1964.

原稿到着：昭和 57 年 3 月 1 日 急載別刷請求先: 藤巻 豊

于113 東京都文京区本郷 3-1-3 順天堂大学医学部耳鼻咽喉科学教室 